\title{
SOME CHARACTERISTICS OF THE RIFT VALLEY IN THE ATLANTIC OCEAN NEAR $36^{\circ} 48^{\prime}$ NORTH*
}

\author{
H.D. NEEDHAM and J. FRANCHETEAU \\ Centre Océanologique de Bretagne, Brest (France)
}

Received August 24, 1973

Revised version received January 29, 1974

\begin{abstract}
-. The Rift Valley between $36^{\circ} 42^{\prime} \mathrm{N}$ and $36^{\circ} 55^{\prime} \mathrm{N}$ in the Atlantic Ocean is $31 \mathrm{~km}$ wide, with half-widths of 12 and $19 \mathrm{~km}$ for the western and eastern sides respectively. Both outer edges of the Rift Valley stand about $1500 \mathrm{~m}$ above an Inner Floor where very fresh pillow lavas occur. The Inner Floor probably includes the locus of new crust; and its bordering slopes, which are particularly well-defined on the western side, limit to less than about $2.5 \mathrm{~km}$ the width of the zone over which new crust may have evolved with little or no vertical displacement. The width of the locus of new crust may be less than $0.5 \mathrm{~km}$ between $36^{\circ} 45^{\prime} \mathrm{N}$ and $36^{\circ} 47^{\prime} \mathrm{N}$, where the deepest slopes of the Rift Valley walls nearly merge. Near $36^{\circ} 50^{\prime} \mathrm{N}$, the Inner Floor accommodates an approximately $1 \mathrm{~km}$ wide, $4 \mathrm{~km}$ long Central High, with a height of up to $250 \mathrm{~m}$. In this area, the locus of new crust may also occupy a very narrow zone; it may lie either along the Central High or along a trough flanking the Central High. The magnetic anomaly pattern indicates that, since the beginning of the Brunhes epoch $\left(6.9 \times 10^{5}\right.$ yr B.P.), the eastern limb has grown approximately twice as fast as the western limb. Using extrapolated spreading rates, the ages of the outer edges of the Rift Valley are 1.3 and $1.7 \mathrm{~m} . \mathrm{y}$. for the eastern and western sides respectively. Comparison with data for the Rift Valley in other parts of the ocean further suggests that the residence time of new crust in the Rift Valley is about $1.5 \mathrm{~m} . \mathrm{y}$. Uplift of crust from the Inner Floor, which may be dominated by lithospheric thickening, may thus be primarily a function of age.
\end{abstract}

\section{Introduction}

Information gathered during the past several years has strengthened the idea that, where present, the Rift Valley of the Mid-Oceanic Ridge is the locus of emplacement of new oceanic crust and accompanying ocean-floor widening $[1,2]$. Some models accounting for magnetic anomaly records [3-6] indicate that the locus is considerably narrower.

The Rift Valley has been crossed hundreds of times by oceanographic vessels but most studies treat it at a scale more appropriate to the Mid-Oceanic Ridge as a whole. During September 1972, as a contribution to the French-American Mid-Oceanic Undersea Survey (FAMOUS) programme, the N/O

\footnotetext{
* Contribution No. 192. Département Scientifique du Centre Océanologique de Bretagne.
}

"Jean Charcot" spent 10 days over a $25 \mathrm{~km}$ long segment of the Rift Valley west of Santa Maria island in the Azores (Fig. 1). We give an outline of morphological and other characteristics of this particular area, and use the evidence to examine aspects of the general problem of the formation of the Rift Valley.

Within the area visited by the "Charcot", deep, inward-facing slopes of the Rift walls border a narrow Inner Floor straddling the axis of the Rift Valley. Mapping the Inner Floor showed the presence of a ridge, or succession of hills, here called the Central High. We lay some emphasis on evidence related to the origin of the Central High and to the shape and character of the Inner Floor because it seems likely that they are relevant to any scheme of crustal growth. For the same reason we comment on the comparative morphology and possible age of the Rift Valley in different parts of the ocean. 


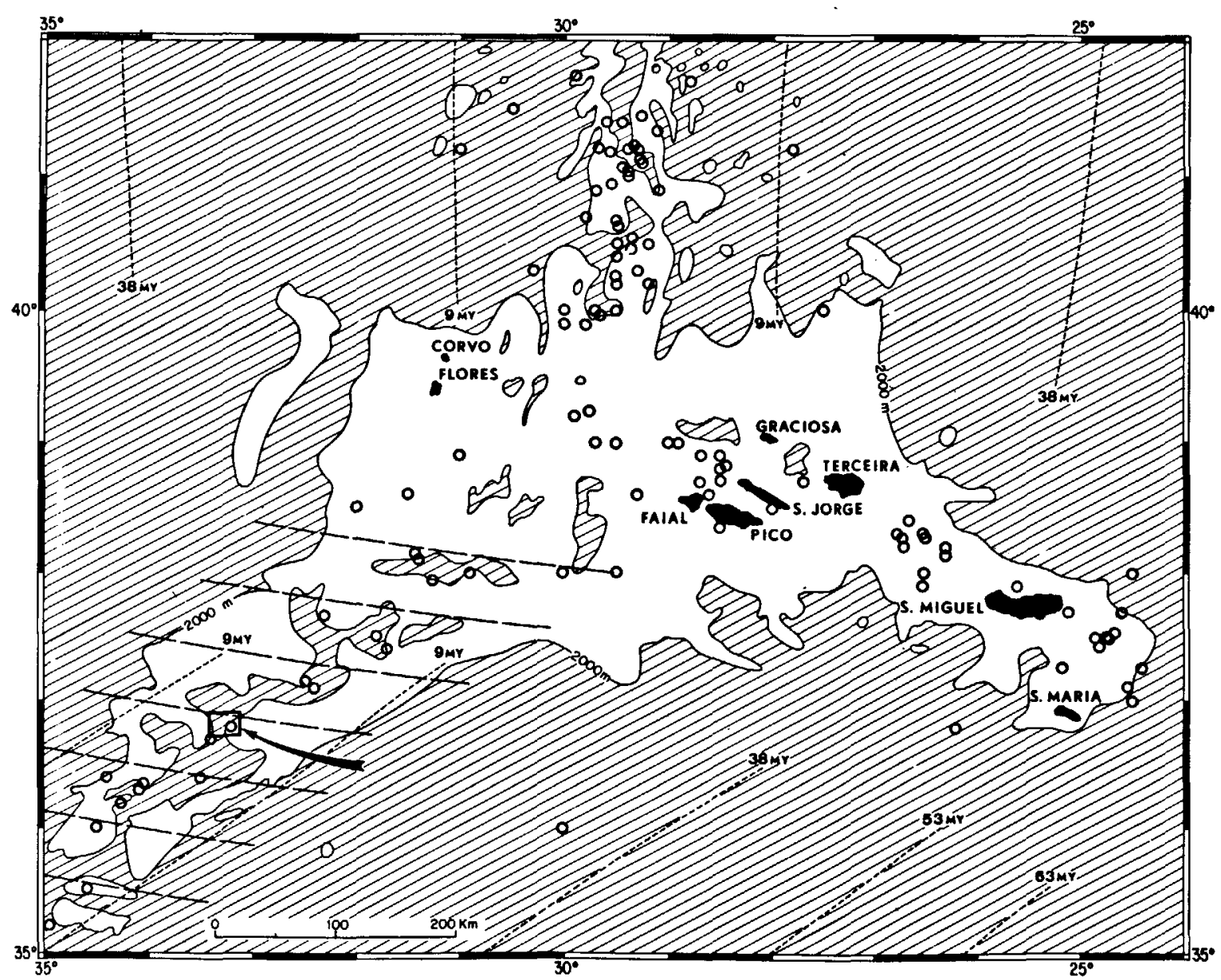

Fig. 1. Mid-Atlantic Ridge in the vicinity of the Azores. Striped areas are deeper than $2000 \mathrm{~m}$; white areas are shallower than $2000 \mathrm{~m}$. Bathymetry from [7]. Heavy dashed lines indicate direction of present opening between North America and Africa [8j. Isochrons (thin dashed lines) are based on magnetic anomaly lineations [9]; labels show age in millions of years. Earthquake epicenters (open circles) are mainly International Seismological Commission determinations (P. Beuzart, personal communication, 1973), and are more numerous north of the Azores; those inside the 9-m.y. isochron are concentrated along Rift Valley and transform faults. Open box near $36^{\circ} 48^{\prime} \mathrm{N}, 33^{\circ} 14^{\prime} \mathrm{W}$ shows location of the area of Rift Valley represented in Figs. 2 and 3.

\section{Morphology}

Mapping was conducted at 5-6 knots, using a standard $12 \cdot \mathrm{kHz}$ wide-beam precision echo-sounder, satellite navigation and taut, moored buoys equipped with radar reflectors. Judging from the shifts required to match sea-floor depths at cross-overs of plotted tracks (Fig. 2), the mean precision of navigation was generally better than about $1 \mathrm{~km}$. The topographic sketch (Fig. 3) is an attempt to show the gross morphology of the Rift Valley, omitting complexities that were not reasonably well resolved. Additional data was collected on station, while the ship was drifting, or steaming at about 1 knot. The reduced speeds led to improved ship's positioning and to clearer resolution of depths recorded on the echograms (Fig. 4).

\subsection{Rift Valley walls}

The dominant strike of the Rift Valley between $36^{\circ} 42^{\prime} \mathrm{N}$ and $36^{\circ} 55^{\prime} \mathrm{N}$ is close to $020^{\circ}$ (Fig. 3). Both northern and southern ends of the Rift Valley inter- 


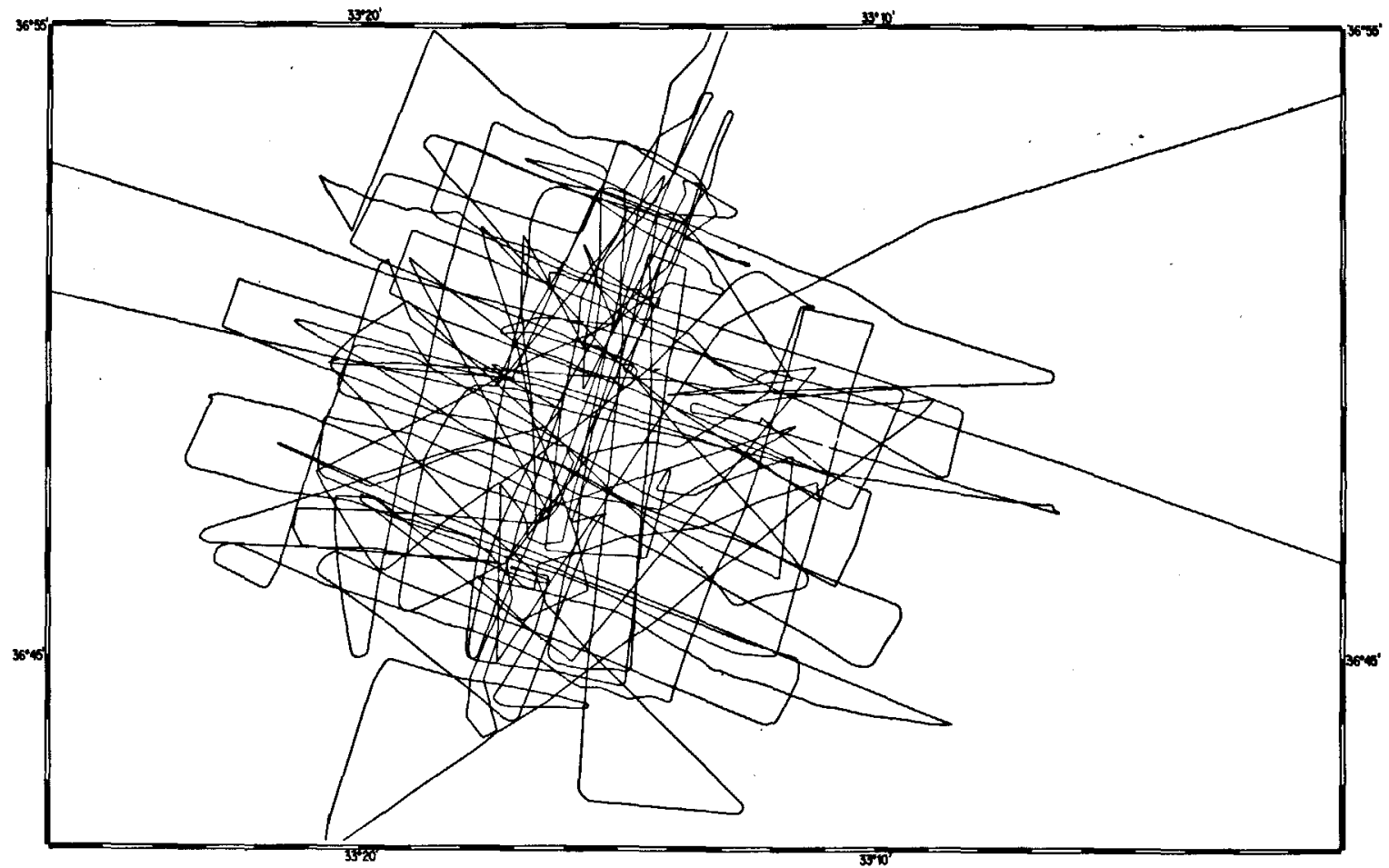

Fig. 2. Track coverage, September 1972, of N/O "Jean Charcot" over Mid-Atlantic Rift Valley (Fig. 1). Navigation by satellite and moored buoys with radar reflectors.

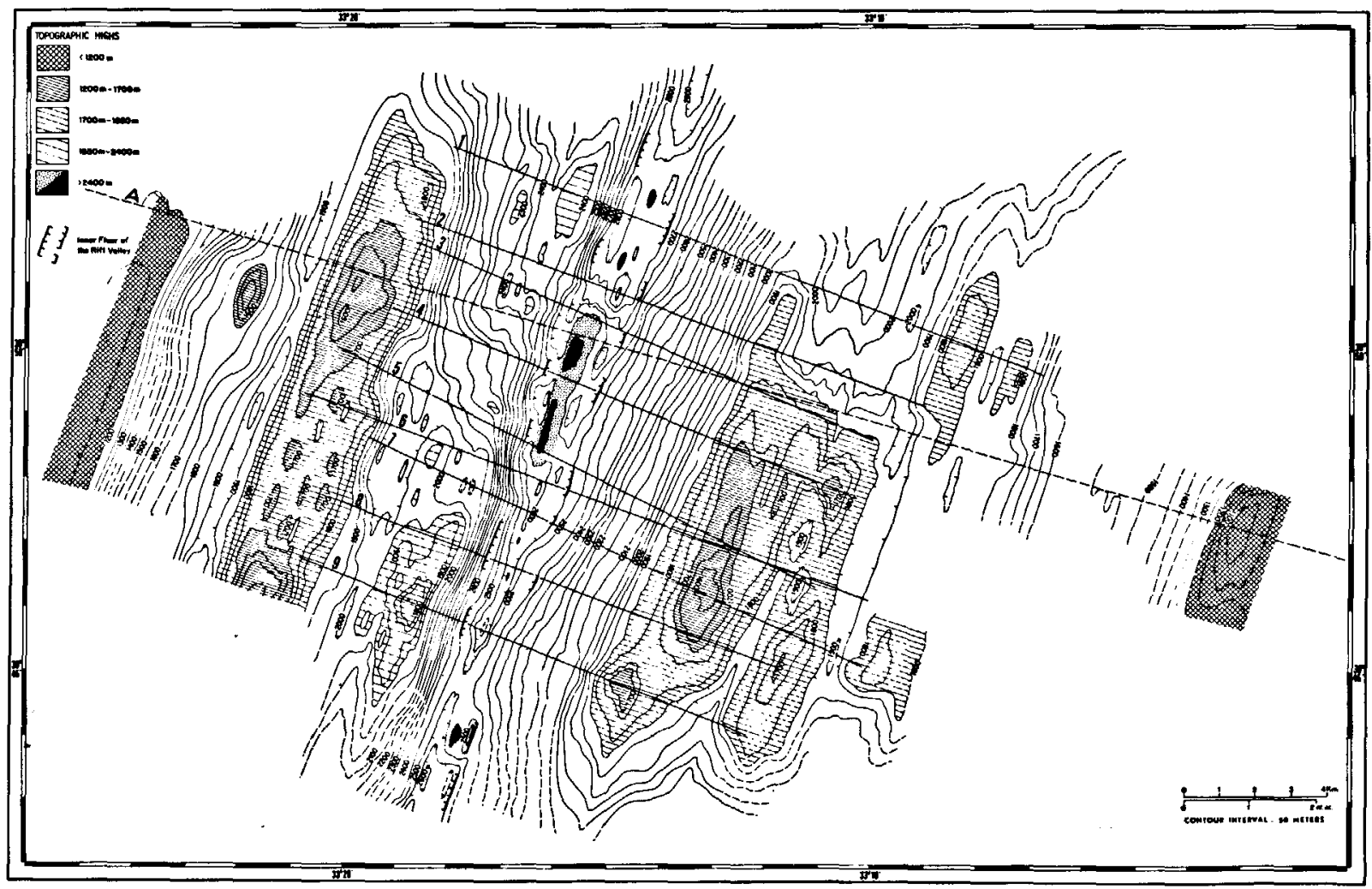

Fig. 3. Topographic map of portion of Mid-Atlantic Rift Valley (Fig. 1 and 2) Depths read from conventional 12-kHz precision echo-sounding records and corrected for sound velocity [10]. Records were obtained at 5-6 knots and show less detail than those obtained at slower speeds during station operations (Fig. 4). Solid lines indicate locations of topographic profiles shown in Fig. 5. Dashed line indicates location of profile A in Fig. 7. 


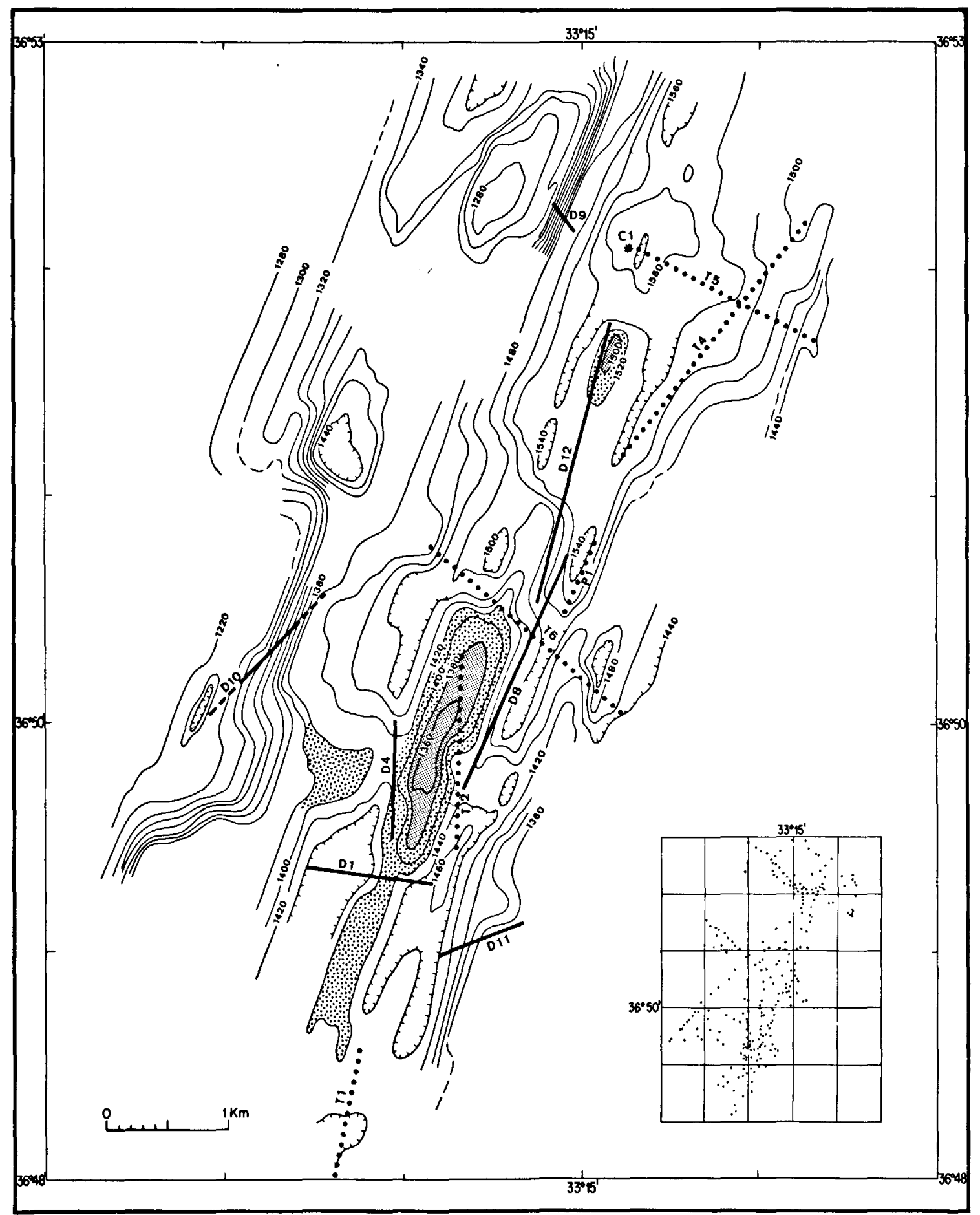

Fig. 4. Topographic map of part of the Inner Floor of the Rift Valley of the Mid-Atlantic Ridge (Fig. 3); based on soundings taken on station while ship was drifting, or steaming at about 1 knot or less. Depths in units of $1 / 400 \mathrm{sec}$ (uncorrected fathoms), read from conventional precision echo-sounding records set for sound velocity in water of $800 \mathrm{fm}(1463 \mathrm{~m})$ per sec. Map drawn using data points shown in bottom right-hand corner inset. Locations are shown for dredging stations (black-bars), towed Troika camera sled and conventional camera stations (dotted lines), and for piston coring station (asterisk). 


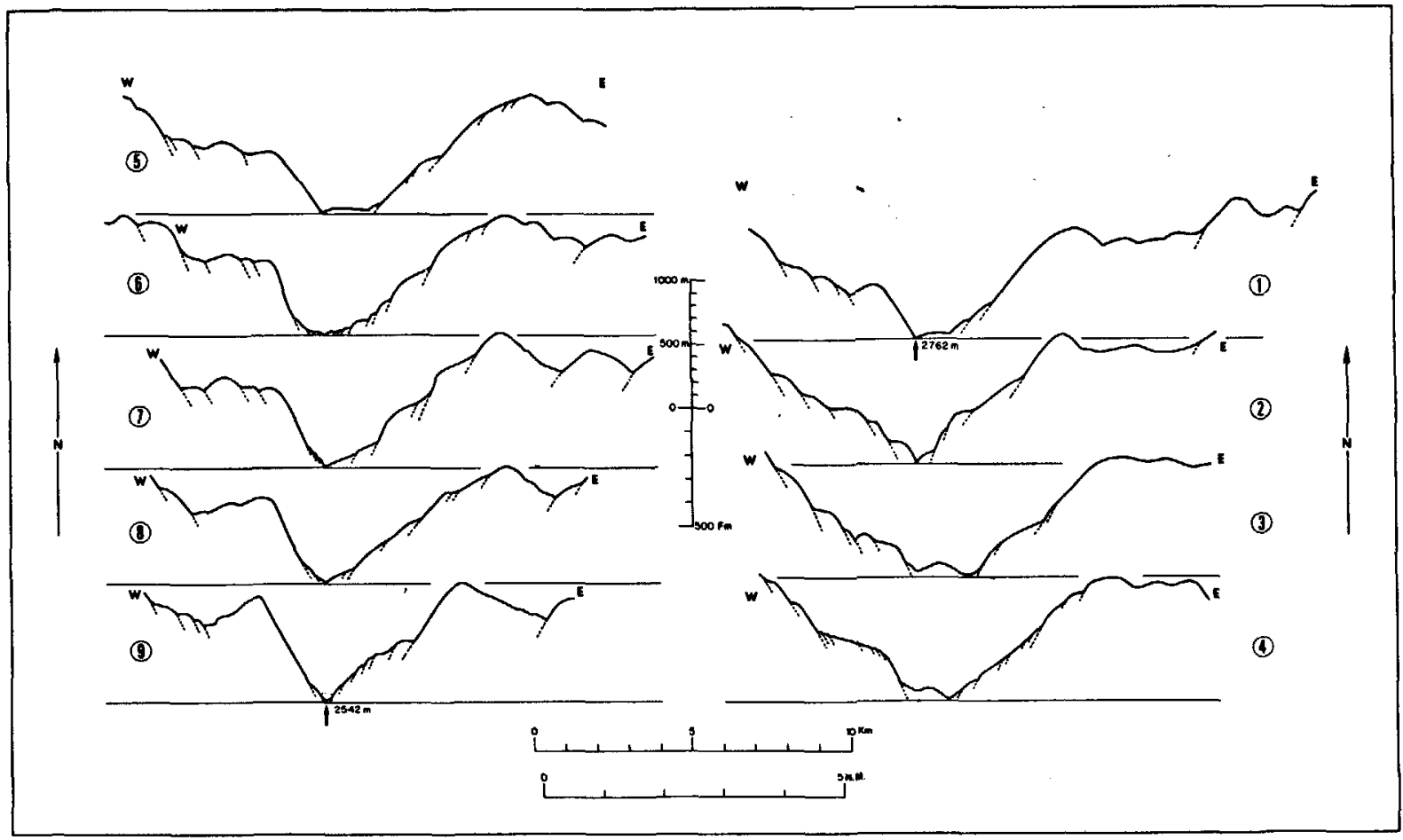

Fig. 5. Topographic profiles of inner part of Rift Valley along lines shown in Fig. 3. Vertical exaggeration is $\times$ 4. Relief in uncorrected units assuming sound velocity in water of $800 \mathrm{fm}(1463 \mathrm{~m})$ per sec. Extensions of scarps as dashed lines emphasizes changes of gradient; some may coincide with locations of normal faults.

sect approximately east-west trending transform faults and their fossil (fracture zone) extensions (J.D. Phillips, personal communication, 1973).

Large linear features, with regional gradients of less than $6^{\circ}$, lie on the walls of the Rift Valley and have the appearance of blocks or steps on which ridges or individual hills are superimposed (Figs. 3, 5 and 6). Steps bordered by topographic deeps appear as isolated topographic highs, $2-4 \mathrm{~km}$ wide and up to $18 \mathrm{~km}$ long. The most prominent steps tend to be continuous along strike between the transform fault/ fracture zone complexes. Step Wl (Fig. 6), however, loses its identity where it deepens to the north near $36^{\circ} 49^{\prime} \mathrm{N}$.

The innermost of opposing steps that are shallower than $1200 \mathrm{~m}$ are taken to represent the inner edges or ridges of the Rift Mountains [1] and to mark the lateral limits of the Rift Valley. The width of the Rift Valley so defined is at least $31 \mathrm{~km}$ and its depth is about $1500 \mathrm{~m}$ (Fig. 3).
Slopes with regional gradients of $6^{\circ}-23^{\circ}$ lie on the inward (closest to the Rift Valley axis) sides of the steps. The steepest inward-facing slope borders the western side of the Inner Floor (Figs. 3 and 6). The back, or outer, slopes of steps that are separated along topographic deeps have regional gradients of $10^{\circ}-16^{\circ}$ (Fig. 6). There is some very limited evidence that gradients of the inward-facing slopes tend to flatten towards the tops of the Rift Valley walls and that those of the outer slopes tend to steepen. The echograms, particularly those recorded at 1 knot or less, show that some of the major structures incorporate smaller units; scarps, or cliffs, with gradients of $45^{\circ}$ to nearly $90^{\circ}$ and with widths of less than a few hundred metres, separate two or more narrow benches on a single regional slope. For example, such benches occur on the inward-facing slope leading down from step El (Figs. 3, 5 and 6).

A considerable area of the walls of the Rift Valley occupies a "reference level" about $1750 \pm 300 \mathrm{~m}$ 


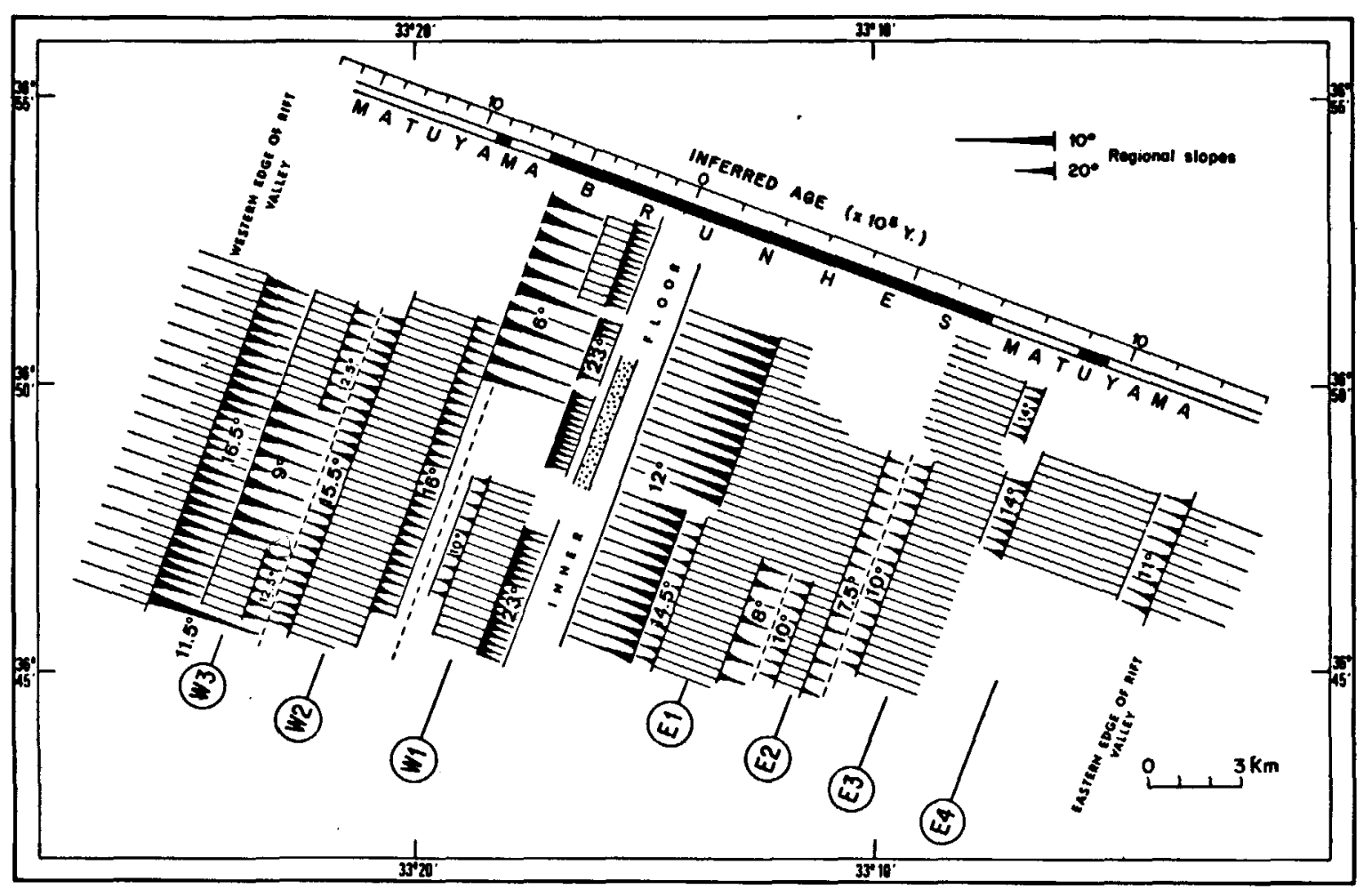

Fig. 6. Diagrammatic representation of regional gradients of Rift Valley slopes read from Fig. 3. Scarps on regional slopes may have very steep to nearly vertical gradients. Striped areas represent steps (regional slopes of $<6^{\circ}$ ). Inferred age-scale is based on spreading rates for the Brunhes magnetic epoch as determined from the magnetic anomaly pattern. Normally magnetized crust indicated by black shading underneath age scale; reversely magnetized crust is unshaded. Geomagnetic time scale from [11].

deep, i.e. about $850 \mathrm{~m}$ above the Inner Floor (Fig. 3; Fig. 7, profile A). Troughs in what we identify as the Rift Mountains [1] stand at a similar elevation above the Inner Floor (Fig. 7, profile A). The part of the Rift Valley deeper than the reference level is about 8 $\mathrm{km}$ wide north of $36^{\circ} 50^{\prime} \mathrm{N}$, and about $4.5 \mathrm{~km}$ wide further south (Fig. 3).

\subsection{Inner Floor and Central High.}

The Inner Floor, lying between deep, inwardfacing slopes of the Rift Valley, has an average width of about $1.5 \mathrm{~km}$ (Fig. 3). However, between $36^{\circ} 45^{\prime} \mathrm{N}$ and $36^{\circ} 48^{\prime} \mathrm{N}$, the slopes deepen towards a narrower zone that is less than about $0.5 \mathrm{~km}$ wide near $36^{\circ} 46^{\prime} \mathrm{N}$ (Fig. 3; Fig. 5, profile 9). North of about $36^{\circ} 48^{\prime} \mathrm{N}$, the main bordering slopes of the Inner
Floor may be up to about $2.5 \mathrm{~km}$ apart (Fig. 5); on the eastern side, they may lie outside the ridge and valley near $36^{\circ} 50^{\prime} \mathrm{N}, 33^{\circ} 15^{\prime} \mathrm{W}$ (Fig. 4). The Inner Floor is about $2500 \mathrm{~m}$ deep at the narrow pass near $36^{\circ} 45^{\prime} \mathrm{N}$. It deepens towards the Rift Valley-transform fault/fracture zone intersections, the maximum depth in the mapped area being close to $2900 \mathrm{~m}$ (Fig. 3).

A prominent topographic feature of the Inner Floor is the ridge, or line of hills, that we refer to as the Central High. The two largest hills occur between $36^{\circ} 48^{\prime} \mathrm{N}$ and $36^{\circ} 51^{\prime} \mathrm{N}$ and stand up to $150-250 \mathrm{~m}$ above flanking troughs which have slightly different depth (Figs. 3 and 4; Fig. 5, profiles 1, 3-5; Fig. 7, profile A). Echo-soundings recorded at slow speeds indicate that some local slopes of the Central High are very steep; regional gradients are similar to those of 
(A)

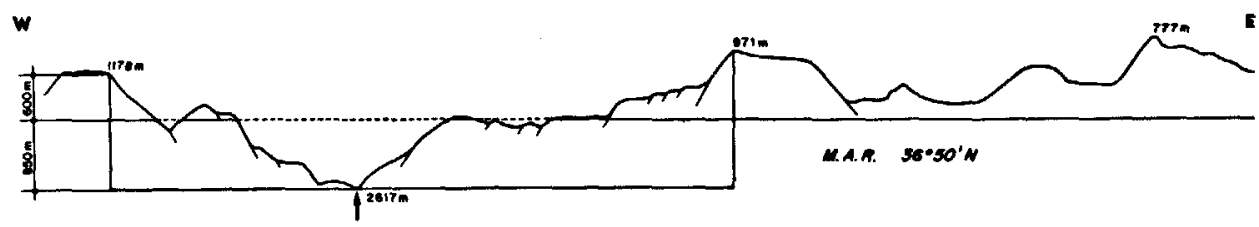

(B)
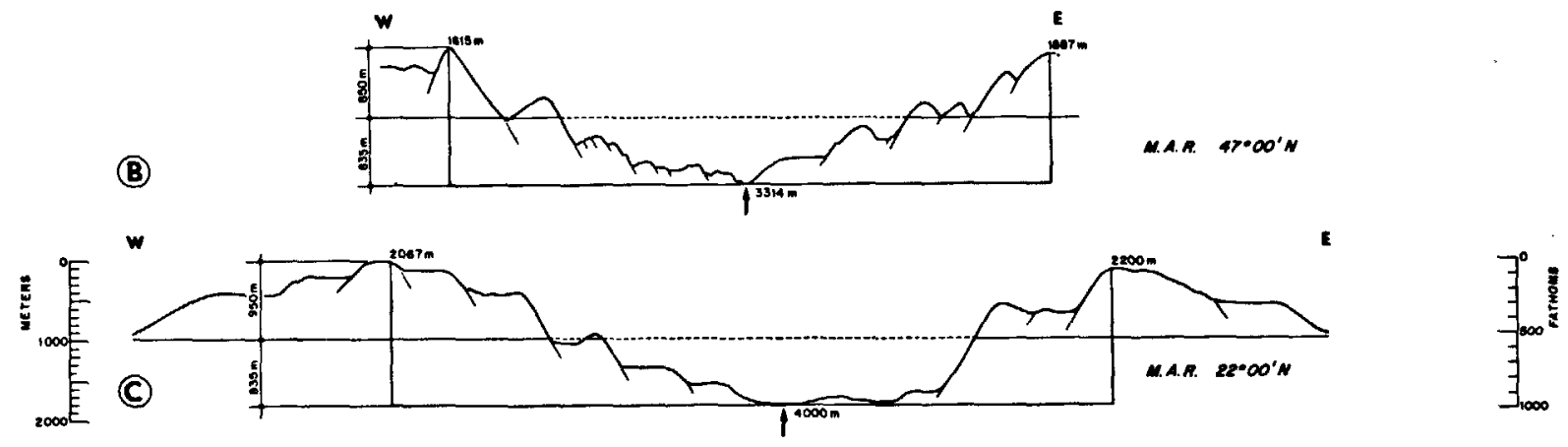

(D)

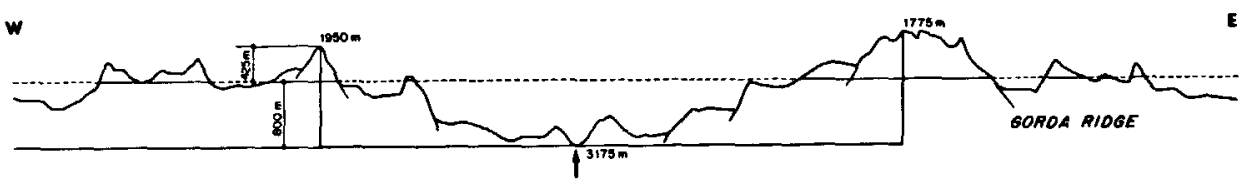

sw

(E)
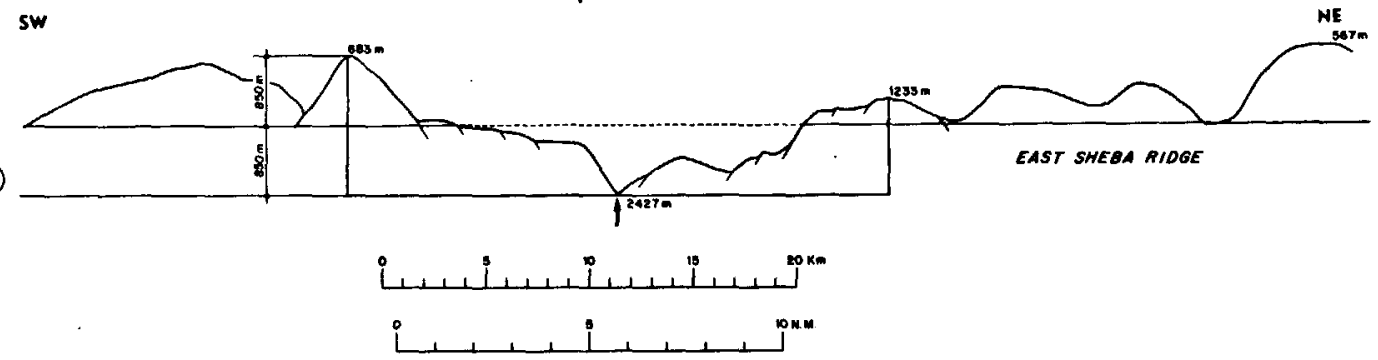

Fig. 7. Topographic profiles across the Rift Valley in five parts of the ocean: Mid-Atlantic Ridge (profiles A, B and C), Gorda Ridge (profile D) and East Sheba Ridge (profile E). The location of profile A is shown in Fig. 3; profiles B, C, D and E are replotted from published data $[12-15]$. Vertical exaggeration is $\times 4$. Units of depth are uncorredted for sound velocity, except for profiles $C$ and $D$ for which the data quoted in the published sources are in corrected metres. Profiles $A, B, C$ and $E$ derived from conventional shipborne, wide-beam precision echo-sounder records; profile $D$ from deep-towed, narrow-beam echo-sounding record. Note similarity in width and shape of the illustrated sections of Rift Valley, and second-order asymmetry; profiles A, C, and possibly B, show relatively broad Inner Floor with topographic high; profile E shows no similar features. It is interesting to speculate whether the two hills in profile D could represent split portions of a Central High of the type seen in profile A. Horizontal lines across profiles are reference levels (section 2.1. this paper).

some of the inward-facing slopes of steps on the walls of the Rift Valley. The Central High is locally asymmetric in cross-section, for example where it is nearly attached to the western wall near $36^{\circ} 50^{\prime} \mathrm{N}$ (Figs. 3 and 4; Fig. 5, profile 4).

The middle line of the Inner Floor near $36^{\circ} 46^{\prime} \mathrm{N}$ leads, along strike towards the north, onto the western slopes of the eastern trough (eastern slopes of the Central High). The left-lateral offset of the westen trough with respect to the middle line of the Inner Floor to the south corresponds approximately with the outward bulge of deep, inward-facing slopes along the western border of the Inner Floor near $36^{\circ} 49^{\prime} \mathrm{N}$, and with the northward deepening, at about the same latitude, of step W1 (Figs. 3 and 6).

At first sight, the Central High seems to be a con- 
structional volcanic feature, or line of features, possibly built over fissures, and with steep pillow flowfronts [16]. Alternatively, it might be argued that it owes at least part of its relief to faulting or that it is a volcano-tectonic structure with the location of intrusion and vulcanism determined by faulting [17].

\subsection{Asymmetry}

The half-width of the Rift Valley from the middle line of the Inner Floor to the adjacent edge of the Rift Mountains is about $12 \mathrm{~km}$ on the western side and about $19 \mathrm{~km}$ on the eastern side (Fig. 3). The regional gradients are about $7^{\circ}$ and $4.5^{\circ}$ for the western and eastern walls respectively, and average regional slopes are steeper on the western than on the eastern wall (Fig. 6). The setting of the Inner Floor with respect to the inner edges of the Rift Mountains is the principal feature of a second order morphological asymmetry that is associated with the walls of the Rift Valley in the mapped area (Fig. 3).

In contrast to the asymmetrical relationships, the middle line of the Inner Floor is nearly symmetrically placed with respect to the inner edges of the opposing steps W2 and E1 which are well defined by the $1750-\mathrm{m}$ isobath, the mean depth of the reference level (Figs. 3 and 6); the distance is about $5 \mathrm{~km}$ on each side.

\section{Chronology from magnetic anomalies}

The magnetic pattern associated with the Rift Valley shows, after removal of the IGRF (1965.0) field [18], the presence of a central positive anomaly with steep gradients. The steep gradients occur about $12.5 \mathrm{~km}$ east of the axis of the Inner Floor and about $3 \mathrm{~km}$ west of the axis (Fig. 8), and define the positive anomaly sufficiently well to determine the location of normally magnetized crust.

We have modelled magnetic profile for the latitude and strike of the Rift Valley in the mapped area, assuming that the structures are cylindrical and strike $020^{\circ}$, and that the normally magnetized crust is of post-Matuyama age $\left(<6.9 \times 10^{5}\right.$ yr B.P.). The best match between the observed positive magnetic anomaly and the synthetic anomaly corresponds to an average opening rate of $2.2 \mathrm{~cm} \mathrm{yr}^{-1}$. One can as- sign a spreading rate to each of the two limbs of the Rift Valley only if a locus for crust of zero age is chosen. Taking this to be the middle line of the Inner Floor (Fig. 3), the spreading rates average over the Brunhes magnetic epoch are about 0.7 and $1.5 \mathrm{~cm}$ $\mathrm{yr}^{-1}$ to the west and east respectively. The western edge of the normally magnetized block that accounts for the axial anomaly lies about $5 \mathrm{~km}$ from the middle line of the Inner Floor, whereas the eastern edge of the normally magnetized block is about $10.5 \mathrm{~km}$ from the middle line (Figs. 6 and 8 ). The estimated spreading rates have a minimum uncertainty of \pm 0.1 $\mathrm{cm} \mathrm{yr}^{-1}$ if one argues that permissible choices for the locus of zero-age crust can be made over a width of at least $1 \mathrm{~km}$.

The evidence from the magnetic anomaly pattern indicates that crust older than $6.9 \times 10^{5}$ yr stands above the reference level on the Rift Valley walls, and that the Rift Valley edges have approximately the same age (1.7 m.y. and 1.3 m.y. to the west and east respectively). The inferred age of the Inner Floor is approximately $10^{5} \mathrm{yr}$, with a spread of possible ages depending on where the limits of the Inner Floor are chosen (section 2.2).

The calculated rates of spreading represent averages over the Brunhes epoch. There is no evidence to show whether or not spreading rates varied within any short period of time, either during the Brunhes epoch, or before it. However, on the basis of one long profile extending beyond the mapped area (Fig. 3 , profile $\mathrm{A}$ ), the average opening rate has been similar (about $2.1 \mathrm{~cm} \mathrm{yr}^{-1}$ ) since the Gilsa-Olduvai events (about $1.7 \times 10^{6} \mathrm{yr}$ B.P.), and the spreading rate to the west has maintained an average value $(0.9 \mathrm{~cm}$ $\mathrm{yr}^{-1}$ ) throughout the Matuyama epoch that is not very different from that for the Brunhes epoch.

\section{Locus of new crust}

The morphology of the Rift Valley, the character of oceanic magnetic anomalies and the present lack of evidence of prevailing large-scale volcanic activity on the Rift Valley walls is consistent with preferential confinement of the youngest crust to the Inner Floor. We note here a few observations, based on photography and sampling of part of the Inner Floor, which focus on the problem of recognizing the sur- 


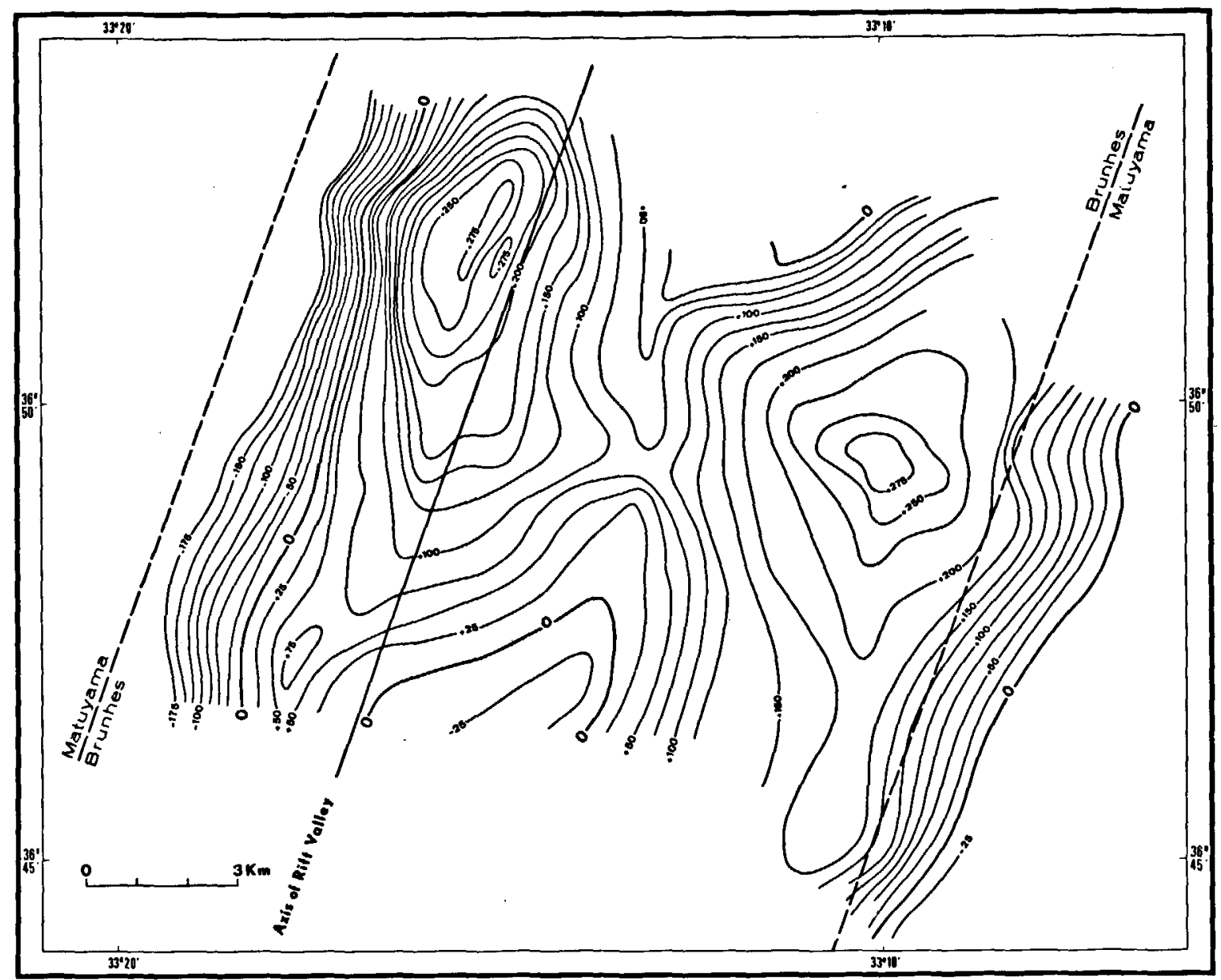

Fig. 8. Magnetic anomaly map of Rift Valley of the Mid-Oceanic Ridge near $36^{\circ} 48^{\prime} \mathrm{N}$. Contour interval 25 gammas. Steep gradients indicate observed edges of central magnetic anomaly of presumed post-Matuyama age. Dashed lines are edges of hypothetical, normally magnetized block accounting for observed positive anomaly.

face expression of the locus of new crust.

The rocks dredged from the "Charcot" are all basalts but represent differences in lava morphology, vesicularity and the content and size of megascopically conspicuous plagioclase and olivine crystals. The dredged rocks also differ in age, using as criteria the preservation of fragile glass rims and visually estimated thicknesses of surface accumulations of palagonife, manganese oxide and semi-indurated calcareous sediment.

Large, weathered, columnar-jointed, quasi-pyramidal pillows, without glass, or with only deep layers of the glassy surfaces preserved, characterize the dredge-hauls from the feet and slopes of scarps on the western side of the Inner Floor (D9 and D10; Fig. 4). In contrast, the other dredge-hauls (Fig. 4) include apparently younger lavas which were not found in D9 or D10.

Small, glassy berlingot (quasi-spheroidal)-shaped fragments with conchoidal fracture, some of which exploded on deck, were dredged on the eastern slope of the eastern trough near $36^{\circ} 49^{\prime} \mathrm{N}$ (D11, Fig. 4), together with basaltic slabs about $2 \mathrm{~cm}$ thick that may be parts of lava pipes [19-21], or fragments of pillow surfaces. Similar slabs were dredged further north (D8, D12, Fig. 4), and glassy fragments resem- 
bling the berlingots of D11, but larger, occur in D1 (Fig. 4). Relatively fresh specimens with megascopically conspicuous olivine crystals were recovered, together with more weathered rocks, from both slopes of the Central High (D4, D8, Fig. 4) and from further north (D12, Fig. 4). The olivine crystals may be accompanied by small plagioclase crystals and, in some specimens, they lie immersed in glassy skins that cover the surface of quasi-ellipsoidal pillows.

The information gathered from the sea-floor photographs supports the evidence of the dredged rocks that exposures of very fresh lava occur within the Inner Floor.

Pillows are commonly quasi-ellipsoidal, phallic, yam-like or twisted; many have well-preserved cracked surfaces with suture-like fissures or show spalling of outer layers, indicating recent, rapid cooling. Several pillow morphologies that are little disrupted, or undisrupted, indicate downslope flow (Fig. 9A). Some flows have sheet-like or intact, massive, and irregular upper layers, and these flows may be associated with slopes that are relatively not too steep (central part of T6, Fig. 4; Fig. 9B). Scattered pillows on sediment-covered surfaces suggest detachment and down-hill tumbling. Sediment-free fields, typically made up almost exclusively of large, angular, broken pillow fragments, resembling rail-road ballast but coarser, may lie in topographic lows or near the feet of slopes (western part of T6, P1, westcentral part of T5, T1, Fig. 4; Fig. 9C).

Relatively thick sediments mask underlying relief on elevated flattish areas of the eastern slopes of the eastern trough (T1, T4, T5, T6, Fig. 4), and there are also areas relatively well covered by sediment on parts of the top of the Central High (T2, Fig. 4). The recovery of an 1-m core of carbonate ooze $(50 \mathrm{~cm})$ and glass particles ( $\mathrm{Cl}$, Fig. 4$)$ from the deep central area north of $36^{\circ} 52^{\prime} \mathrm{N}$ indicates the thickness of some accumulations of sediment within the boundaries of the Inner Floor. Locally, concentrated or dispersed glass fragments are a feature of the sediment cover, and some of the sediment surfaces have a linear grain; piling-up of sediment may further suggest current activity.

Small, steep-sided plateaux occur above and east of the eastern trough of the Inner Floor (T4 and T5, Fig. 4) and on the Central High (northern part of T2, Fig. 4; Fig. 9D). The edges of the plateaux may be small lava flow-fronts or faults outlined by the sediment cover.

Some differences of rock-types, lava morphologies and sediment cover are attributed to local differences of structural setting; but the weight of the combined evidence of the photographs and rocks, although clearly limited, is that at least the slopes of the eastern trough and Central High are partially covered by fresh lavas.

The possibility that the locus of new crust may be confined to a very narrow zone is more appealing on grounds of magnetics [3-6] than the alternative that loci of new crust are spread across a relatively broad zone within the Inner Floor. The morphology indicates that, south of $36^{\circ} 48^{\prime} \mathrm{N}$, the locus of new crust, or the locus where new crust will be emplaced, may occupy a zone as narrow as $0.5 \mathrm{~km}$ or less (section 2.2). If it occupies a similarly narrow zone further north, and there is no large offset (section 2.2), then it could lie either along the eastern trough or be the Central High itself.

The presence of sediment-covered, flattish surfaces on the Central High (Fig. 9D), and its near attachment to the Rift Valley walls, may perhaps be taken as evidence that the Central High is not of purely constructional origin but involves uplift. Implications of such an inference are that the locus of new crust (plate boundary) lies along a flanking trough, that uplift starts almost immediately after crust is created [22], and that it involves crustal blocks of limited $(2-3 \mathrm{~km})$ length along strike. A consequence would be the development of transverse fractures that interrupt the continuity of the Central High along strike. The occurrence of large, fresh, olivine crystals in some of the dredged rocks (T8 and T 12, Fig. 4), and of very fresh flows on part of the Central High (T6, Fig. 4; Fig. 9B), could possibly reflect the presence of such a fracture near $36^{\circ} 50.5^{\prime} \mathrm{N}$.

On the other hand, if the Central High is a locus of crustal emplacement, built over fissures and of purely constructional origin, then uplift of crust presumably does not take place until a minimum distance or crustal age is attained, either within the Inner Floor or at its borders. Any prominent fissures within the Inner Floor, if analogous to those of terrestrial fissural fields, are likely to be discontinuous along strike, and offsets of the locus of new crust would be expected. In addition, Central High-type volcanoes, 

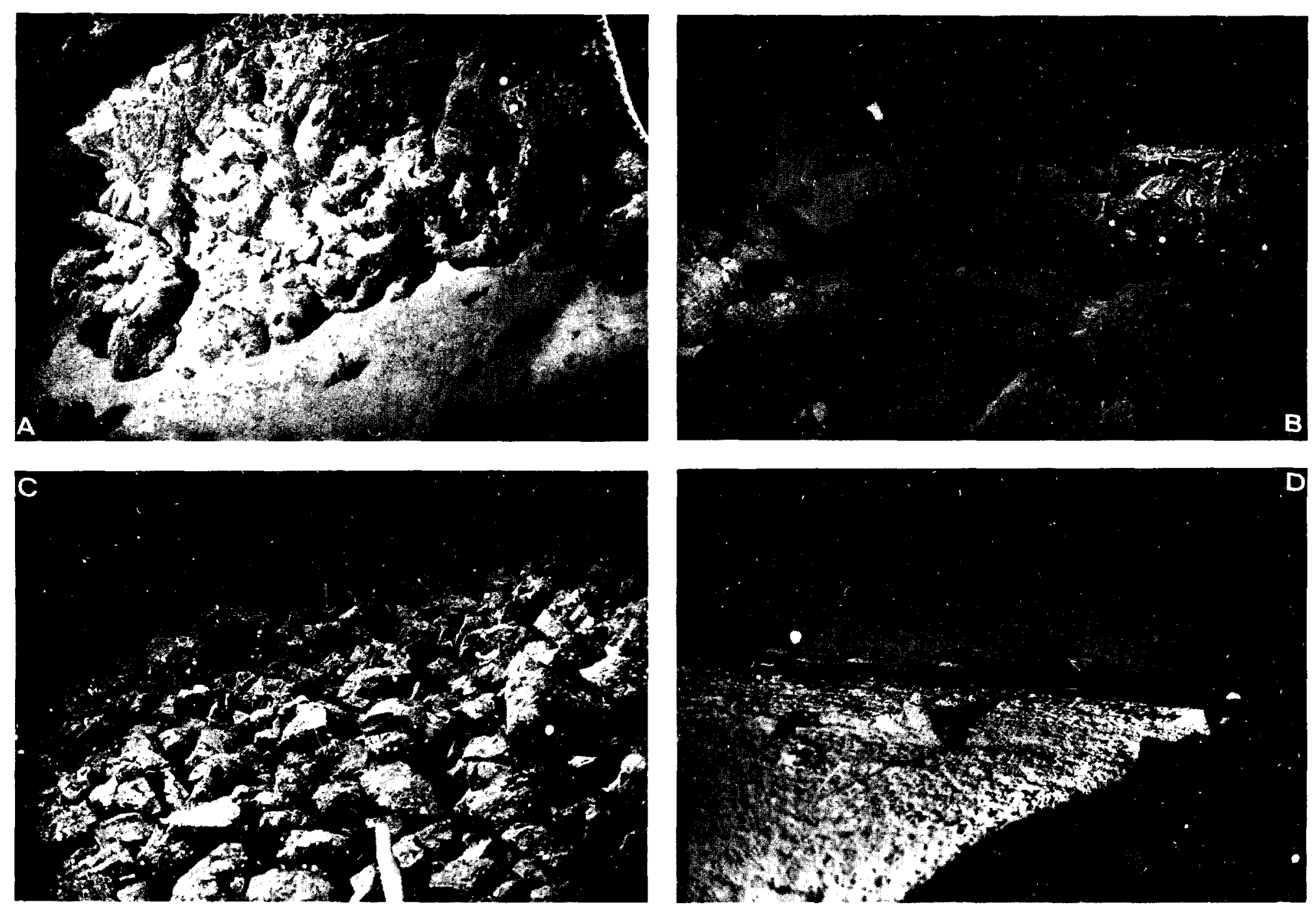

Fig. 9. Troika photographs of four types of terrain in the Inner Floor of the Rift Valley. A. Scrap partially covered by downslope flow of pillow lavas, in sharp contrast with sediment-covered surface (T1, Fig. 4). B. Intact pillows with cracked selvages, on gentler slope than A (T6, Fig. 4). C. Field of broken, angular, columnarjointed, pillow-lava fragments having average intermediate diameters of approximately $30 \mathrm{~cm}$ (T1, Fig. 4). D. Linear-edged plateau covered with pock-marked sediment and with intact pillow lavas and fragments in background. 
or split portions of them, may migrate laterally across the Inner Floor before uplift.

\section{Comparison with other parts of the Rift Valley}

Major features of the segment of Rift Valley described in this paper appear to be quite typical of the Rift Valley as a whole. We have made use, for comparative purposes, of maps and profiles drawn from several parts of the Rift Valley where the tectonic and magnetic setting is relatively well defined, namely from $47^{\circ} \mathrm{N}$ [12] and $22^{\circ} \mathrm{N}$ [13] in the North Atlantic; from the East Sheba Ridge in the northwestern Indian Ocean [15]; from the Gorda Ridge in the Pacific $[14,22]$; and from the Carlsberg Ridge in the Indian Ocean $[23,24]$.

Heights of the inner edges of the Rift Mountains, as we define them, are from 1.2 to $1.8 \mathrm{~km}$ above the axis of maximum depth of the Rift Valley; a representative mean is about $1.5 \mathrm{~km}$ (Fig. 7). The width of the Rift Valley varies from about 30 to $35 \mathrm{~km}$. The walls are characterized by steps of rather uniform width and arrangement, but some steps appear to be coupled together and the number of steps may vary. Differences of elevation between many of the large adjacent steps are $200-400 \mathrm{~m}$. The distance between the inner slopes of the major steps resting at the reference level (section 2.1 ) ranges from about $8 \mathrm{~km}$ to 16 km (Fig. 7). The morphology of the Rift Valley may change over short distances along strike and the steeper wall may switch from one side of the Rift Valley axis to the other.

Inner Floors of the Rift Valley have a range of widths from less than $2 \mathrm{~km}$ to about $9 \mathrm{~km}$ and some contain features that may be similar to the Central High near $36^{\circ} 48^{\prime} \mathrm{N}$ in the Atlantic (section 2.2; Fig. 7). Topographic highs in the deepest part of the Rift Valley near $47^{\circ} \mathrm{N}$ were mapped as a continuous feature longer than $9 \mathrm{~km} \mathrm{[12]} \mathrm{and,} \mathrm{immediately} \mathrm{to} \mathrm{the}$ south, depressions and hummocks have been described [25]. Topographic highs have also been reported to occur near $22^{\circ} \mathrm{N}$ in the Atlantic [13] and within the deepest part of the Rift Valley of the Gorda Ridge [14].

An estimate of spreading rate derived from magnetic data is available for at least one limb of the segments of the Rift Valley that we have compared.

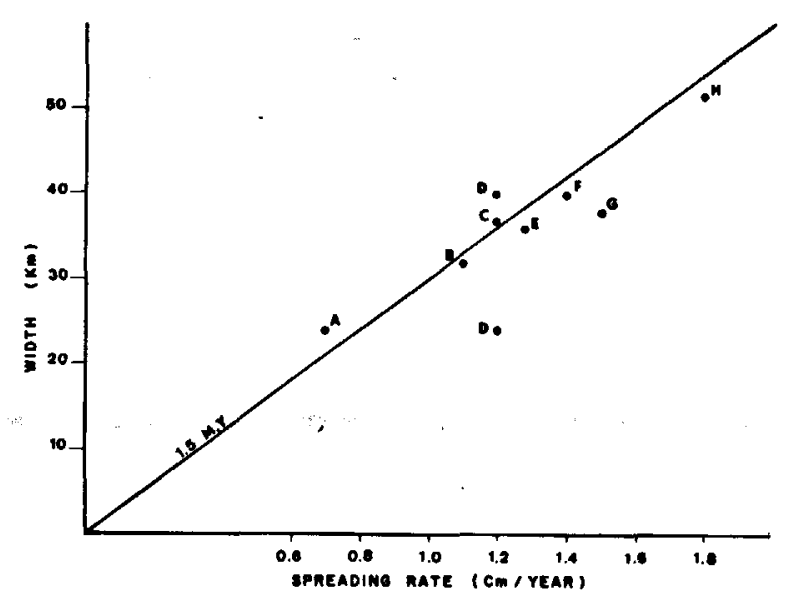

Fig. 10. Graph showing constancy of residence time of crust in the Rift Valley inferred from magnetic chronology. Plotted widths represent twice the distance (on one side or the other) between the deepest part of the Rift Valley and the first well-defined edge or ridge that appears to mark the inner limit of the Rift Mountains. Corresponding spreading rates are half-plate separation rates measured normal to the Rift Valley axis. Rift Valley, Mid-Atlantic Ridge: $\mathrm{A}$ and $\mathrm{G}$, $36^{\circ} 48^{\prime} \mathrm{N}$, western and eastern limbs (this paper); $B$ and $\mathrm{E}$, $45^{\circ} 30^{\prime} \mathrm{N}$, eastern and western limbs $[26,27] ; \mathrm{F}, 22^{\circ} \mathrm{N}$, western limb [13]. Rift Valley, Carlsberg Ridge: $\mathrm{C}$ and $\mathrm{H}, 5^{\circ} \mathrm{N}$, northeastern and southwestern limbs (estimate from $[23,24])$. Rift Valley, Gorda Ridge: D, $41^{\circ} 10^{\prime} \mathrm{N}$, western limb ([14,22], T. Atwater, personal communication, 1973); $\mathrm{D}^{\prime}$, well off the $1.5-\mathrm{m} . y$. isochron, is from Spies and Mudie [14] (Fig. 7D of this paper).

Differences of observed half-widths of the Rift Valley may reflect different spreading rates (Fig. 10) which, in turn, may explain an asymmetric location of the axis of a segment of Rift Valley with respect to the inner edges of the Rift Mountains. Computed rates suggest that the age of the edges of the Rift Valley is, in the cases examined, approximately $1.5 \mathrm{~m} . y$. (Fig. 10). Implications are that the residence time of new crust in the Rift Valley - an important parameter for models relating to the origin and dynamic stability of the Rift Valley - is approximately constant, and that approximate mean spreading rates can be deduced from the morphology of the Rift Valley.

Assuming uplift of the Inner Floor of the Rift Valley (section 6), the deduced average rate, $0.1 \mathrm{~cm}$ $\mathrm{yr}^{-1}$, is the same as the rate of uplift in the Gorda Ridge Rift Valley that was found using foraminiferal evidence [28], and is the same as the inferred rate of 
subsidence for the first million years after crustal creation on the Juan de Fuca Ridge [29] . Other estimates of subsidence rates are an order of mag. nitude smaller [30].

\section{Explanations for the origin of the Rift Valley}

The vertical relief and the width of the Rift Valley preclude that the valley is either a simple, downfaulted graben in brittle lithosphere of uniform thickness under isostatic equilibrium [31], or that it is associated with uplift brought about by the injection of quasi-horizontal dykes [32]. The presence of a negative residual gravity anomaly near $45^{\circ}-46^{\circ} \mathrm{N}$ is evidence that the Rift Valley is not in isostatic equilibrium. However, the narrowness of the zone of mass deficiency underlying the Rift Valley implies that recovery of equilibrium is efficient and rapid outside of this zone [33].

\subsection{Osmaston's model}

Osmaston [34] has adopted the suggestion [31] that the Rift Valley floor is maintained out of isostasy by viscous drag of upwelling magma against colder fossilized margins of newly created lithosphere. In Osmaston's explanation the buoyant force applied to each plate increases as the separation continues until the shear strength of one of the two plates is exceeded. The part of the plate between the surface of rupture and the axis of crustal emplacement then rises in response to load reduction. Uplift is thus considered to be the result of upthrust faulting in the upper part of the Rift Valley walls, or just outside them. In a steady state, the level at which the quenched upper surface of the upwelling material is established should stay approximately the same, and the rise of either of the two plates would result in the creation of a new step in the Rift Valley. Blocks that have risen too high above their level of isostatic balance are considered to subside through reverse faulting in the Rift Mountains province. Ostmaston assumes that plate accretion is symmetrical and attributes morphological asymmetry of the Rift Valley to lack of simultaneity of uplift of the plates.

Features of Osmaston's model are appealing. The great relief of the Rift Valley is explained, and the possibility that the axis of accretion changes from one side to the other of the Inner Floor of the Rift Valley can be accounted for. Furthermore, some degree of asymmetry of the Rift Valley walls can be expected if upthrust faulting is predominant on one side. A serious difficulty with the model is that no evidence of thrust faulting is seen in focal mechanisms for Mid-Oceanic Ridge events, even from local sonobuoy arrays; in addition, there is no firm evidence for an upward decrease of the vertical interval between steps on the walls.

\subsection{Discussion}

We have noted that elevation of crust of the walls above the Inner Floor of the Rift Valley may be associated with the age of the sea floor (sections 3 and 5), as are the subsidence rates of oceanic crust on the flanks of the Mid-Oceanic Ridge $[30,35]$. If this is true, a rough estimate of average accretion rates for the last 1 or 2 m.y. can be made from the slopes of the Rift Valley walls, and constraints are placed on the physical mechanisms responsible for uplift (section 5).

When two newly formed segments of lithosphere separate, it seems likely that the brittle portions of the plates thicken rapidly. In Parker and Oldenburg's thermal model [36], they are 12-14 km thick under the edges of the Rift Valley where we suggest that the floor is about 1.5 m.y. old (Fig. 10). The brittle lithosphere may be $3-5 \mathrm{~km}$ thick [36-38] under the Inner Floor (section 2.2). Possibly, there is a critical age at which the thickness of the newly formed plate segment is such that the plate segment rises with the adjacent older portion of plate, producing decoupling at or near the axis of accretion, where mechanical strength of the lithosphere is least. If the uplift occurs always when a given plate thickness is reached, then the uplift of the plate may be nearly constant; and if, as in Osmaston's model, the level of emplacement of new material is also approximately constant, a new step would be created after each phase of uplift. The stepmaking might well be accompanied by vulcanism.

As the plate gradually thickens, the uplift of the plate between the axis of intrusion and some point in the Rift Mountains would take place as a whole, and all faults would be normal; normal "unfaulting" (faulting on planes dipping away from the Rift Val- 
ley) might take place in the Rift Mountains. In this interpretation, termination of uplift of new crust would be associated with a horst-like feature (see Fig. 7 for possible examples), and the finite width of the Rift Valley would be related to the time-constant of the process of recovery of initially depressed crust to near isostatic equilibrium, the recovery itself being dominated by the process of lithospheric thickening. The growth of the Inner Floor (section 2.2), both in width and in the vertical relief of constructional features within it, would be limited by the uplift process. Uplift, which is irreversible, could contribute to asymmetry in total accretion if it is not required that decoupling takes place precisely at the axis of accretion, or that uplift of the Rift Valley walls is always in phase. Differences of uplift history may also contribute to differences along the strike of even short segments of the Rift Valley.

The tentative model that we have outlined fits the limited observations noted in this paper but several implications are worth stressing. The Inner Floor should be younger than the Rift Valley walls and fossil Inner Floors, or parts of Inner Floors, should be preserved on the walls. The faults on both walls should be anthithetic (e.g. [39]), and the dip of the fault surfaces should decrease towards the edges of the Rift Valley. External rotation of steps on the walls should be recorded, and may have been recorded $[40]$, in the remanent magnetization vector frozen in the magnetized layer. Active normal faulting, and accompanying large earthquakes, should be associated with the deepest scarps of the Rift Valley and, possibly, with scarps outside the edges of the Rift Valley. Other major scarps should be essentially fossil fault surfaces.

\section{Acknowledgments}

We thank Commandant Priser, officers and crew on board the "Jean Charcot". The scientific party was V. Renard (Chief Scientist), P. Beuzart, J.C. Duplessy, J. Francheteau, D. Greenwalt, R. Hekinian, P. Juhel, S. Monti, H.D. Needham and P. Taylor. J. Phillips made a bathymetric map available prior to the cruise. We are grateful to V. Renard for providing the navigational data and the magnetic anomaly map; to X. Le Pichon, J. Morgan, J. Phillips, V. Renard, F.
Vine and others for constructive discussions; to G. Le Grand and B. Berthe for help with data reduction; to D. Carré and S. Monti for drafting text figures; and to Y. Potard and N. Uchard for typing the manuscript. We have appreciated the support of C. Riffaud. X. Le Pichon and V. Renard read an earlier version of the manuscript and made critical suggestions.

\section{References}

1 B.C. Heezen, M. Tharp and M. Ewing, The floors of the oceans, I. The North Atlantic, Geol. Soc. Am., Spec. Paper 65 (1959) 122 pp.

2 B.C. Heezen, Géologie sous-marine et déplacements des continents, in: La Topographie et la Géologie des Profondeurs Océaniques, Colloq. Int. Centr. Nat, Rech. Sci. 83 (1959) 295-804.

3 D.H. Matthews and J. Bath, Formation of magnetic anomaly pattern of Mid-Atlantic Ridge, Geophys. J. R. Astron. Soc. 13 (1967) 349-357.

4 C.G.A. Harrison, Formation of magnetic anomaly pattern by dyke injection, J. Geophys. Res. 73 (1968) 2137-2142.

5 F.J. Vine, Magnetic anomalies associated with Mid-Ocean Ridges, in: R.A. Phinney, ed., The History of the Earth's Crust (Princeton Univ. Press, Princeton, N.J., 1968) 73-89.

6 T. Atwater and J.D. Mudie, Deep tow magnetic measurements and their implications for the emplacement of oceanic crust (abstract), Trans. Am. Geophys. Union 54 (1973) 251.

7 E. Uchupi, Bathymetric atlas of the Atlantic, Caribbean and Gulf of Mexico, Woods Hole Oceanogr. Inst., Tech. Rep. 71-72 (1971), unpublished.

8 J. Francheteau, Plate tectonic model of the opening of the Atlantic Ocean South of the Azores, in: D.H. Tarling and S.K. Runcorn. eds. Implications of Continental Drift to the Farth Sciences, 1 (Academic Press, New York, N.Y., 1973) 197-201.

9 W.C. Pitman III, and M. Talwani, Sea-floor spreading in the North Atlantic, Geol. Soc. Am. Bull. 83 (1972) 619-646.

10 D.J. Matthews, Tables of the velocity of sound in pure water and sea water for use in echo-sounding and soundranging, Hydrographic Dept. Admiralty, London, H.D.

- 282 (1939) $52 \mathrm{pp}$.

11 A. Cox, Geomagnetic reversals, Science 163 (1969) 237-245.

12 M.N. Hill, A median valley of the Mid-Atlantic Ridge, Deep-Sea Res. 6 (1959) 193-205.

$13 \mathrm{Tj}$. H. van Andel and C.O. Bowin, Mid-Atlantic Ridge between $22^{\circ}$ and $23^{\circ}$ north latitude and the tectonics of mid-ocean rises, J. Geophys. Res. 73 (1968) 1279-1298.

14 F.N. Spiess and J.D. Mudie, Small-scale topographic and 
magnetic features, in: A.E. Maxwell, ed., The Sea, 4 (Inter-science, New York, N.Y., 1970) 205-250.

15 A.S. Laughton, R.B. Whitmarsh and M.T. Jones, The evolution of the Gulf of Aden, Phil. Trans. R. Soc., Lond. Ser. A 267 (1970) 227-266.

16 J.G. Moore, R. Cristofolini and A. Lo Guidice, Development of pillows on the submarine extension of recent lava flows, Mount Etna, Sicily, U.S. Geol. Survey Prof. Paper 750-C (1971) C89-C97.

17 A. Ritmann, Volcanoes and their activity (Interscience, New York, N.Y., 1962) 305 pp.

18 IAGA Commission 2 Working Group 4, International Geomagnetic Reference Field 1965.0, J. Geophys. Res. 74 (1969) 4407-4408.

19 J.G. Moore, Petrology of deep-sea basalt near Hawaii, Am. J. Sci. 263 (1965) 40-52.

20 R.L. Larson, Near-bottom studies of the East Pacific Rise crest and tectonics of the mouth of the Gulf of California, Ph. D. Thesis, University of California, San Diego, Calif. (1970) 164 pp.

21 R. Hekinian, M. Chaigneau and J.L. Cheminée, Popping rocks and lava tubes from the Mid-Atlantic Rift Valley at $36^{\circ} \mathrm{N}$, Nature 245 (1973) 371-373.

22 T.M. Atwater and J.D. Mudie, Block faulting on the Gorda Rise, Science 159 (1968) 729-731.

23 D.H. Matthews, F.J. Vine and J.R. Cann, Geology of an area of the Carlsberg Ridge, Indian Ocean, Geol. Soc. Am. Bull. 76 (1965) 675-682.

24 J.R. Cann and F.J. Vine, An area on the crest of the Carlsberg Ridge: petrology and magnetic survey, Phil. Trans. R. Soc., Lond. Ser. A 259 (1966) 198-217.

25 B.D. Loncarevic, C.S. Mason and D.H. Matthews, MidAtlantic Ridge near $45^{\circ}$ north, I. The Median Valley, Can. J. Earth Sci. 3 (1969) 327-349.

26 B.D. Loncarevic and R.L. Parker, The Mid-Atlantic Ridge near $45^{\circ} \mathrm{N}$, XVII. Magnetic anomalies and ocean-floor spreading, Can. J. Earth Sci. 8 (1971) 883-898.

27 P.J. Bhattacharyya and D.I. Ross, Mid-Atlantic Ridge near $45^{\circ} \mathrm{N}$, Bathymetry Map (Marine Sciences Branch, Dept. of the Environment, Ottawa, 1972).
28 G.A. Fowler and L.D. Kulm, Foraminiferal and sedimentological evidence for uplift of the deep-sea floor, Gorda Rise, nor theastern Pacific, J. Mar. Res. 28 (1970) 321-329.

29 W.G. Melson and T.H. Simkin, Volcanism and bathymetric symmetry, southern Juan de Fuca Ridge, Trans. Am. Geophys. Union 54 (1973) 133.

30 H.W. Menard, Elevation and subsidence of oceanic crust, Earth Planet. Sci. Lett. 6 (1969) 275-284.

31 N.H. Sleep, Sensitivity of heat flow and gravity to the mechanism of sea-floor spreading, J. Geophys. Res. 74 (1969) 542-549.

32 J.D.A. Piper and I.L. Gibson, Stress control of processes at extensional plate margins, Nat. Phys. Sci. 238 (1972) 83-86.

33 J.M. Woodside, The Mid-Atlantic Ridge near $45^{\circ} \mathrm{N}, \mathrm{XX}$. The gravity field, Can. J. Earth Sci. 9 (1972) 942-959.

34 M.F. Osmaston, Genesis of Ocean Ridge median valleys and continental rift valleys, Tectonophysics 11 (1971) $387-405$.

35 J.G. Sclater, R.N. Anderson and M.L. Beil, Elevation of ridges and evolution of the central Eastern Pacific, $J$. Geophys. Res. 76 (1971) 7888-7915.

36 R.L. Parker and D.W. Oldenburg, Thermal model of ocean ridges, Nat. Phys. Sci. 242 (1973) 137-139.

37 T.J.G. Francis and I.T. Porter, Median valley seismology: the Mid-Atlantic Ridge near $45^{\circ} \mathrm{N}$, Geophys. J. R. Astron. Soc. (1973) in press.

38 D.J. Weidner and K. Aki, Focal depth and mechanism of ocean ridge earthquakes. J. Geophys. Res. 78 (1973) $1818-1831$.

39 S.C. Cande, J.L. Labrecque and K. McCamy, Application of linear filtering to marine magnetic anomalies, paleopoles and ridge crest processes (abstract), Trans. Am. Geophys. Union 54 (1973) 252.

40 M. Mattauer, Les Déformations des Matériaux de l'Ecorce terrestre (Hermann, Paris, 1973) 493 pp. 